\title{
Exposure of Captive Wild Mammals to Heavy metals Contamination in Jodhpur Zoological Garden, Rajasthan, India
}

\author{
Varsha Gupta ${ }^{1}$ and Prakash Bakre ${ }^{2}$ \\ ${ }^{1}$ Mahatma Gandhi Institute of Applied Sciences, JECRC Foundation, Jaipur-302022, India \\ ${ }^{2}$ JECRC University, Sitapura Industrial area, Jaipur-302022, India
}

\begin{abstract}
Study of environmental contamination in the wildlife, free-ranging or those caged in the zoos, is a challenging venture. This is primarily because of difficulty in obtaining samples, which can be at the most opportunistic, from these animals. Feces of wild animals were used as biological indicator of exposure in wild animals caged and exposed to the ambient air pollution of urban habitat. Various metal contents in mammals of Jodhpur (India) zoo were in the range of $72.8 \pm 1.36$ (Panthera leo) to $22.4 \pm 1.97$ (Axis axis) ppm d/w. Cadmium was in range between $3.80 \pm 0.69$ (Panthera leo) to $0.60 \pm 0.32$ (Macaca mulatta) ppm d/w. Chromium was in rage of $6.91 \pm 2.66$ (Axis axis) to 2.66 \pm 1.08 (Macaca mulatta) ppm d/w. Copper was in range between $19.0 \pm 1.17$ (Panthera leo) to $7.0 \pm 3.51$ (Macaca mulatta). Whereas zinc was found in range of $66.20 \pm 0.67$ (Axis axis) to $10.2 \pm 1.33$ (Panthera tigris) ppm $d / w$. Analysis of feed and water along with the soil in cages which is receiving particulate air pollutants indicates that air pollution is the primary cause due to high density of traffic in the area.
\end{abstract}

Keywords: Air pollution, Heavy metals, Bioindicator, Feces, Wild mammals.

\section{Introduction}

Mammals are one of the most diversified of all creatures on earth today. They range from tiny bat species to the largest Blue Whales. The overall mammalian species known worldwide is about 4,500 species [1]. Globally, mammals are threatened by destruction and degradation of ecological habitats, caused by a variety of factors including agricultural intensification, urbanization, pollution and climate change. Human disturbance, overexploitation of natural resources and invasive species are also major threats [2].

Zoological gardens (zoos) are institutions or facilities in which animals are confined within enclosures, displayed to the public, and in which they may also be bred. The history of modern zoological gardens, however, started some 200 years ago with the creation of the first public zoological garden. Since that time, large numbers of zoological gardens have been established in all parts of the world [3]. Globally, zoological gardens are known to offer great opportunities for entertainment and education, and to contribute to wildlife conservation and promote scientific research, especially for environmentalists and conservationists, as the rate of extinction of wild life increases.

Most of the zoos which were once located on the outskirts of the cities and towns are now surrounded by human activities like vehicular traffic and industries. Some of the famous zoos like municipal corporation zoo at Ahmadabad and forest departmental at Ahmadabad have vehicular traffic too close to premises. All these activities result in heavy metal pollution, which may be adversely affect the health and wellbeing of the wild animals housed in such protected areas.

Jodhpur is tourist place in western Rajasthan. The Jodhpur zoo in the city is located in Umaid Pubic Garden which also houses a public library and a Government museum. The library and museum is centrally located whereas zoo is situated on the periphery of the park. The zoo is surrounded by metal roads on all the sides. Similarly metal roads divide the zoo into various sections such as carnivore section, deer section, primate section, bird section etc, many transport companies are also located near the cages where most of the carnivores i.e. tiger, lion and panther are housed. On these metalled roads petrol driven vehicles are frequently playing.

Ingestion of $\mathrm{Pb}$ containing paint from bars and walls have been reported to be a significant cause of death among captive wild animals including monkeys, bears, raccoons, armadillos etc. [4], [5]. Similar situation was reported for domestic animals like dogs, cats, goats, cattle etc. [6]. The highest body burdens of $\mathrm{Pb}$ were reported in mammals near urban areas with dense vehicular traffic and also near metal mines and smelters [7].

Signs of lead toxicosis in cows (Bos bovins) included muscle tremors, blindness, dribbling urine and drooling. Proximity to smokestacks of metal smelters was positively associated with increased level of lead in hair (manes) of horses and in tissues of small mammals which was consistent with the results of soil and vegetable analysis. Several studies have reported concentrations of metals in wild mammals living in highly contaminated area near smelters [8], chlor-alkali plant [9], [10] verges of heavily-used highways[11] and mines or mine waste sites [12-13], [14]. 
Various methods were employed to assess and draw a concentration profile of a variety of pollutants that might reach the wildlife habitats and wildlife itself. In fact the human race in its selfish design has used wildlife species as biological indicators to study the ambient concentration of the toxicants in his own ecosystem, both urban and industrial. However, 39mammals, which are much closer to human beings, are rarely used. Rats, captured from either side of the highways indicated that the body concentration of the lead was directly proportional to the distance from the highway [15].

Bat was the first mammal used by analysis of its guano as bio-indicator for pesticidal pollution as well as mercury exposure [16], [17], [18] and analysis of feces for Cd intake in humans [19]. Sileo et al [20] recorded concentration of cadmium, lead, zinc, copper in the feces of deer killed near smelters to check the degree of metals pollution. David et al [21] have found that fecal level of metals were four fold higher in urban than the rural rats.

A pilot study to monitor $\mathrm{Pb}$ contamination in wild herbivores from the protected areas of Rajasthan, India [22] suggests that exposure to heavy metals can be studied using herbivore dung as a bio-indicator. In the continuation of this, study was also done in mammalian fauna of Keoladeo National Park, Bharatpur [23] and Sariska Tiger Reserve, Alwar [24]. Scat samples of the mammals, vegetation, and soil samples clearly indicate the extent to which the mammalian fauna is exposed to metal contamination.

However, the method of sacrificing or killing of animal may appear more scientific, but is certainly ethically unsound. Given the concern for loss of animal lives for scientific investigation, and the increasing biological poverty of the planet earth, there is an urgent need for developing biological indicator which will not involve killing of animals. To overcome this problem it was proposed to use feces / scat / fecal matter as bio-indicators or as a biomarkers to study exposure to heavy metals.

\section{Material And Methods}

Fresh scat samples of mammals housed in the animal section of Jodhpur zoo, India, were collected from the cages with the help of zoo staff. Samples were brought to the laboratory and freeze dried. Scat samples were collected from the cases of following mammalian species; chital (Axis axis), nilgai (Boselaphus tragocamelus), chinkara (Gazella gazella), blackbuck (Antilope cervicapra), Asiatic lion (Panthera leo persica), tiger (Panthera tigris), rhesus macaque (Macaca mulatta), ibex (Capra ibex)To ascertain the source of contamination water and food samples (meat, fish, vegetation, vegetables, fruits, cereals, pulses, sugar etc.) of this zoo were also collected. Another, suspected source of contamination was suspended particulate matter settling on the floor of cages, hence soil samples were also taken from cages of animals. Scat and soil samples were stored in the plastic zip lock bags and water samples in the sterilized plastic containers.

For analysis of sample $0.5 \mathrm{gm}$ of dry scat / vegetation / feed / soil were weighed and taken in the hard Borosil glass tube. Concentrated nitric acid and perchloric acid were added to each sample in 4:1 ratio. Sample was kept in water bath for 5 to 6 hours or until it was digested completely and became clear. When the sample was clear 3 to 4 drops of $\mathrm{H}_{2} \mathrm{O}_{2}(30 \%)$ were added to neutralize and to dissolve the fat. After cooling each sample was diluted upto $10 \mathrm{ml}$ with deionized water and transferred to sterilized Borosil glass vial and stored at room temperature prior to analysis.

Water samples were transferred into beakers, cleaned with double distilled and acidified distilled water, and concentrated keeping on a hot plate in a flame hood adding 12 to $15 \mathrm{ml}$ of analytical grade $\mathrm{HNO}_{3}$. The heating was continued till such time the sample became colorless and clean. However, samples were never allowed to dry completely. By and large, nitric acid alone was adequate for complete digestion of water samples. $\mathrm{HClO}_{4}$ was added only to those samples which had high organic matter which were always treated in advance (pre-treated) with nitric acid before adding perchloric acid. If necessary, more $\mathrm{HNO}_{3}$ was added and volume brought down to the lowest quantity $(10$ to $25 \mathrm{ml})$ before precipitation occurred. After completing the digestion, beakers were allowed to cool. Samples were diluted upto $10 \mathrm{ml}$ with double distilled water.

Entire metal analysis was done by using GBC Advanta ver. 1.31 Atomic Absorption Spectrophotometer at 217 $\mathrm{nm}$ for lead, $228.9 \mathrm{~nm}$ for cadmium, $324.7 \mathrm{~nm}$ for copper, $213.9 \mathrm{~nm}$ for zinc and $357.9 \mathrm{~nm}$ for chromium. Results are presented in $\mu \mathrm{g} / \mathrm{g}$ (ppm) dry weight and $\mu \mathrm{g} / \mathrm{ml}$ (ppm) wet weight.

\section{Results And Discussion}

Concentration of lead, cadmium, chromium, copper and zinc in scat / fecal matter was analysed for every mammalian species captivated in a similar environment of zoo. These results show a trend of variation in metal content according to the feeding habits as well as activity level of mammals. The mammals were categorized in three major groups i.e. herbivores that feed on green leaves (vegetation), vegetables, green grains, fruits, cereals, pulses etc., omnivores which feed on both vegetation and meat or fish and carnivores type which are fed meat and fish. Metals concentrations indicate gross exposure. The concentration of lead analyzed in fecal matter of captive zoo wild mammals was in the range of $72.8 \pm 1.36$ (Panthera leo) to $22.4 \pm 1.97$ (Axis axis) ppm $\mathrm{d} / \mathrm{w}$. Cadmium was in range between $3.80 \pm 0.69$ (Panthera leo) to $0.60 \pm 0.32$ (Macaca mulatta) $\mathrm{ppm} \mathrm{d} / \mathrm{w}$. 
Chromium was in rage of $6.91 \pm 2.66$ (Axis axis) to $2.66 \pm 1.08$ (Macaca mulatta) ppm d/w. Copper was in range

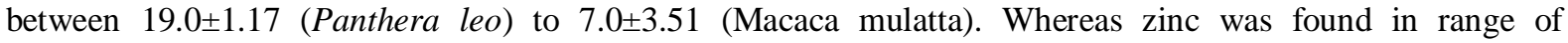
$66.20 \pm 0.67$ (Axis axis) to 10.2 \pm 1.33 (Panthera tigris) ppm d/w (Table 1).

The background levels of lead, cadmium, chromium, copper and zinc in food were analysed. The feed of every mammalian species was analyzed and it was found that lead was present in each sample of food which was provided to zoo mammals (Table 2). The concentration of lead was found in the range of 1.8 to $4.81 \mathrm{ppm}$ $\mathrm{d} / \mathrm{w}$. Cadmium was found in range of 0.8 to $1.3 \mathrm{ppm} \mathrm{d} / \mathrm{w}$. The concentration of chromium was found in the range of 0.31 to $4.15 \mathrm{ppm} \mathrm{d} / \mathrm{w}$. Copper was analysed in the range of 4.5 to $20.4 \mathrm{ppm} \mathrm{d} / \mathrm{w}$. The concentration of zinc in feed samples was observed in the range of 2.2 to $20.7 \mathrm{ppm} \mathrm{d} / \mathrm{w}$.

The background level of lead, cadmium, chromium, copper and zinc in soil and water were also analysed. The concentration of lead in soil was found to be significantly high $8.6 \pm 0.56 \mathrm{ppm} \mathrm{d} / \mathrm{w}$. Water was found to have $2.2 \pm 1.08 \mathrm{ppm} \mathrm{w} / \mathrm{w}$. Water was found to have much less concentration of lead compared to soil which had higher concentration, indicating its deposition from air. Cadmium concentration in soil and water were significantly lower i.e. $2.4 \pm 1.01 \mathrm{ppm} \mathrm{d} / \mathrm{w}$ and $1.4 \pm 0.98 \mathrm{ppm} \mathrm{w} / \mathrm{w}$. Chromium concentration in soil and water were $11.25 \pm 1.01 \mathrm{ppm} \mathrm{d} / \mathrm{w}$ and $0.19 \pm 0.11 \mathrm{ppm} \mathrm{w} / \mathrm{w}$ respectively. Copper concentration of soil and water were found to be $61.4 \pm 2.25 \mathrm{ppm} \mathrm{d} / \mathrm{w}$ and $1.2 \pm 0.81 \mathrm{ppm} \mathrm{w} / \mathrm{w}$. In case of soil and water zinc content was $41.4 \pm 1.69 \mathrm{ppm} \mathrm{d} / \mathrm{w}$ and $0.6 \pm 0.03 \mathrm{ppm} \mathrm{w} / \mathrm{w}$ respectively (Table 2 ).

Lead, cadmium, chromium, copper and zinc concentration were found in considerable amount in the biological samples (fecal matter/ feed) and non-biological (soil/water) samples collected from Jodhpur zoo. Concentration of metals in particularly in fecal matter samples from zoo is much higher than the wild animals like white tailed deer feeding near smelter [20]. Jodhpur zoo apparently is with polluted one for the obvious reason that it is situated in Umaid Pubic Garden which also houses a public library and a Government museum. The library and museum is centrally located whereas zoo is situated on the periphery of the park. The zoo is surrounded by metal roads on all the sides, many transport companies are also located near the cages where most of the carnivores are housed. On these metalled roads petrol as well as diseal driven vehicles are frequently playing. Among the carnivores lion, Panthera leo feces had maximum concentration, may be because lion cage is positioned very close to transport companies. The food is comparatively less contaminated but high concentration in the soil from the cages indicates heavy deposition of particulate matter. Leonzio and Massi et.al. [25] had shown that metal concentration in feces normally equals that in food. Obviously the additional exposure was through plausible route of inhalation. The load of lead in fecal matter almost exceeded what is present in the food material. Fortunately, NEERI [26] had conducted air monitoring studies showing the presence of metals in the urban air of city which appears to be the possible route of exposure and presence of metals indicates the gross exposure of wild mammals cages in zoos in immediate past 24 hours. Soils receive potentially toxic elements from both natural and wide range of anthropogenic sources, including the weathering of primary minerals, mining, fossil fuel combustion, the metallurgical, electronic, and chemical industries, and waste disposal and automobile exhaust. Earlier studies have quantified deposition of metals in the vicinity of the highway or traffic dense area, either by measurement by dry depositions fluxes at various distances from road, or by calculating soil and vegetation concentrations and assuming that the soil acts as long term store, hence effectively integrating the deposition [27], [28]. Lead concentrations as high as 6835, 1180 and $682 \mathrm{ppm}$ dry weight have been reported in soil, vegetation and invertebrates, respectively [29], [28].

Metal depositions are associated with a wide range of sources such as small scale industries (including battery production, metal products, metal smelting and cable coating industries) ; brick kilns ; vehicular emissions ; re-suspended road dust and diesel generator sets. These can all be important contributors to the contamination found in vegetables. In general, coal combustion is an important source, because Indian coal is of relatively poor quality and has high heavy metal contents. Additional potential sources of heavy metals in field locations in urban and peri-urban areas include irrigation water contaminated by sewage and industrial effluent leading to contaminated soils and vegetables. Other sources can include unsafe or excess application of (sometimes banned) pesticides, fungicides and fertilizers such as sewage sludge [30].

Metals belong to the group of foreign materials that are excreted into bile and their ratio of concentration in bile verses plasma is greater than 1.0 and may be as high as 10 to 1000 . Since liver is in a very advantageous position for removing toxic materials from blood after their absorption, it can prevent their distribution to other parts of the body. Furthermore, because the liver is the main site of biotransformation of toxic agents the metabolites may be excreted into bile [31]. Lead is absorbed in gastrointestinal tract by two steps process. It is first absorbed from lumen and then excreted into the intestinal fluid [32]. Upon oral ingestion about 5 to $10 \%$ of lead is absorbed and usually less then $5 \%$ of what is absorbed is retained [33]. Thus about $99.5 \%$ of total ingested lead is excreted through feces. Out of this $90 \%$ is coming out without being absorbed and $9.5 \%$ after being absorbed and metabolized leaving only $0.5 \%$ to be deposited in various body tissues.

Fecal matter analysis method's distinct advantages over tissue analysis are that the exposure can be measured on daily basis, it does not involve killing or even disturbing the wild mammals, it represents the metal 
eliminated which has been incorporated due to gross exposure (inhalation, ingestion or dermal exposure) in a locality. Thus, it can be concluded that wild mammals housed in Jaipur zoo are exposed to metallic pollution (air and water). Our study has firmly established the value of fecal matter analysis as bioindicator of heavy metal contamination. At least our study holds out a promise where scat can be used, since it does not involve either disturbing or killing of an animal, as useful bioindicator. The study can be further extended to freeranging wild animal which are exposed to contaminants that are emitted by vehicles plying on roads within the protected areas.

\section{Tables}

As results are given in Table 1 and Table 2. Table 1 shows the concentrations of heavy metals in feces of captive zoo mammals, whereas Table 2 shows the concentrations of heavy metals in food, water which was provided to zoo mammals and concentration of metals in soil samples.

Table 1: Metal Concentration in Scat Samples of Wild Mammals Housed in Jodhpur Zoological Garden, Rajasthan.

\begin{tabular}{|c|c|c|c|c|c|c|c|c|c|c|c|c|}
\hline S.N. & Species & $\mathrm{N}$ & $\mathrm{Pb}(\mathrm{ppm})$ & & $\mathrm{Cd}(\mathrm{ppm})$ & & $\mathrm{Cr}(\mathrm{ppm})$ & & $\mathrm{Cu}(\mathrm{ppm})$ & & $\mathrm{Zn}(\mathrm{ppm})$ & \\
\hline & & & Mean \pm S.D. & S.E. & Mean \pm S.D. & S.E. & $\begin{array}{l}\text { Mean } \quad \pm \\
\text { S.D. }\end{array}$ & S.E. & $\begin{array}{l}\text { Mean } \quad \pm \\
\text { S.D. }\end{array}$ & S.E. & $\begin{array}{l}\text { Mean } \quad \pm \\
\text { S.D. }\end{array}$ & S.E. \\
\hline 1 & $\begin{array}{l}\text { Antilope } \\
\text { cervicapra }\end{array}$ & 21 & $47.2 \pm 2.11$ & 0.460 & $1.41 \pm 0.98$ & 0.213 & $\begin{array}{l}4.12 \quad \pm \\
1.01\end{array}$ & 0.191 & $14.0 \pm 0.78$ & 0.17 & $\begin{array}{l}28.4 \quad \pm \\
2.55\end{array}$ & 0.556 \\
\hline 2 & Axis axis & 36 & $* 22.4 \pm 1.97$ & 0.328 & $1.0 \pm 1.02$ & 0.17 & $\begin{array}{l}\# 6.91 \quad \pm \\
2.66\end{array}$ & 1.05 & $15.4 \pm 0.39$ & 0.065 & $\begin{array}{l}\# 66.2 \quad \pm \\
0.67\end{array}$ & 0.111 \\
\hline 3 & $\begin{array}{l}\text { Gazella } \\
\text { gazella }\end{array}$ & 13 & $52.0 \pm 2.26$ & 0.627 & $1.0 \pm 0.91$ & 0.541 & $\begin{array}{l}5.02 \quad \pm \\
0.98\end{array}$ & 0.43 & $12.8 \pm 3.25$ & 0.902 & $\begin{array}{l}39.9 \quad \pm \\
4.31\end{array}$ & 1.19 \\
\hline 4 & $\begin{array}{l}\text { Boselaphus } \\
\text { tragocamelus }\end{array}$ & 29 & $44.4 \pm 1.05$ & 0.195 & $0.62 \pm 0.22$ & 0.04 & $\begin{array}{l}3.91 \\
0.65\end{array}$ & 0.151 & $7.40 \pm 1.31$ & 0.243 & $\begin{array}{l}54.4 \quad \pm \\
5.01\end{array}$ & 0.931 \\
\hline 5 & Capra ibex & 20 & $51.0 \pm 2.56$ & 0.572 & $1.40 \pm 0.91$ & 0.203 & $\begin{array}{l}6.01 \\
1.12\end{array}$ & 0.815 & $11.2 \pm 0.65$ & 0.145 & $\begin{array}{ll}24.8 & \pm \\
2.07 & \end{array}$ & 0.642 \\
\hline 6 & $\begin{array}{l}\text { Macaca } \\
\text { mulatta }\end{array}$ & 30 & $54.1 \pm 2.05$ & 0.374 & $* 0.60 \pm 0.32$ & 0.058 & $\begin{array}{l}* 2.66 \quad \pm \\
1.08\end{array}$ & 0.153 & $* 7.0 \pm 3.51$ & 0.641 & $\begin{array}{l}35.61 \quad \pm \\
3.02\end{array}$ & 0.552 \\
\hline 7 & $\begin{array}{l}\text { Panthera leo } \\
\text { persica }\end{array}$ & 15 & $\# 72.8 \pm 1.36$ & 0.351 & $\# 3.80 \pm 0.69$ & 0.178 & $\begin{array}{l}3.01 \quad \pm \\
0.65\end{array}$ & 0.030 & $\begin{array}{l}\# 19.0 \quad \pm \\
1.17\end{array}$ & 0.302 & $\begin{array}{l}48.4 \quad \pm \\
2.04\end{array}$ & 1.04 \\
\hline 8 & $\begin{array}{l}\text { Panthera } \\
\text { tigris }\end{array}$ & 10 & $58.8 \pm 0.25$ & 0.079 & $3.0 \pm 0.68$ & 0.215 & $\begin{array}{l}6.18 \quad \pm \\
0.44\end{array}$ & 0.015 & $13.2 \pm 2.29$ & 0.724 & $\begin{array}{l}* 10.2 \quad \pm \\
1.33\end{array}$ & 0.42 \\
\hline
\end{tabular}

$\mathrm{N}=$ Number of samples, $\mathrm{ND}=$ Not detectable, $*$ =Lowest Mean values, \# = Highest Mean values, Metal concentration in $\mu \mathrm{g} / \mathrm{g}(\mathrm{ppm})$ dry weight and $\mu \mathrm{g} / \mathrm{ml}(\mathrm{ppm})$ wet weight.

Table 2 : Metal Concentration in Feed, Soil, and Water Samples of from Jodhpur Zoological Garden, Rajasthan.

\begin{tabular}{|c|c|c|c|c|c|c|c|c|c|c|c|c|}
\hline S.N. & Sources & $\mathrm{N}$ & $\mathrm{Pb}(\mathrm{ppm})$ & & $\mathrm{Cd}(\mathrm{ppm})$ & & $\mathrm{Cr}(\mathrm{ppm})$ & & $\mathrm{Cu}(\mathrm{ppm})$ & & $\mathrm{Zn}(\mathrm{ppm})$ & \\
\hline I & Food & & Mean \pm S.D. & S.E. & Mean \pm S.D. & S.E. & Mean \pm S.D. & S.E. & Mean \pm S.D. & S.E. & Mean \pm S.D. & S.E. \\
\hline 1 & Meat & 12 & $4.81=0.25$ & 0.072 & $0.81 \pm 0.12$ & 0.034 & $2.15 \pm 0.21$ & 0.06 & $11.0 \pm 0.13$ & 0.037 & $3.4 \pm 0.81$ & 0.23 \\
\hline 2 & Fish & 09 & $3.0 \pm 0.01$ & 0.003 & $1.0 \pm 0.35$ & 0.116 & $1.99 \pm 0.07$ & 0.02 & $12.4 \pm 0.14$ & 0.046 & $5.4 \pm 1.03$ & 0.343 \\
\hline 3 & Vegetation & 11 & $* 1.8 \pm 0.54$ & 0.163 & $1.21=0.17$ & 0.051 & $1.26 \pm 0.04$ & 0.012 & $20.4 \pm 1.6$ & 0.483 & $22.7 \pm 1.4$ & 0.422 \\
\hline 4 & Vegetables & 15 & $2.2 \pm 1.77$ & 0.457 & $* 0.6 \pm 0.14$ & 0.036 & $1.01 \pm 0.031$ & 0.008 & $18.5 \pm 2.9$ & 0.749 & $20.4 \pm 2.5$ & 0.64 \\
\hline 5 & Fruits & 06 & $3.5 \pm 0.91$ & 0.372 & $1.3 \pm 0.04$ & 0.016 & $2.04 \pm 1.10$ & 0.44 & $11.2 \pm 1.25$ & 0.512 & $6.0 \pm 1.05$ & 0.430 \\
\hline 6 & Cereals & 11 & $2.73 \pm 0.52$ & 0.157 & $0.9 \pm 0.31$ & 0.093 & $4.15 \pm 1.09$ & 0.32 & $5.05 \pm 0.45$ & 0.135 & $7.6 \pm 0.92$ & 0.27 \\
\hline 7 & Pulses & 07 & $2.6 \pm 0.21$ & 0.079 & $1.21=0.41$ & 0.155 & $3.15 \pm 0.88$ & 0.33 & $7.0 \pm 0.91$ & 0.344 & $4.2 \pm 1.06$ & 0.40 \\
\hline 8 & Sugar & 10 & $2.8 \pm 0.52$ & 0.166 & $0.8 \pm 0.05$ & 0.015 & $0.31=0.01$ & 0.003 & $4.5 \pm 0.3$ & 0.101 & $2.2 \pm 1.03$ & 0.32 \\
\hline II & Water & 08 & $2.2 \pm 1.08$ & 0.382 & $1.4 \pm 0.98$ & 0.347 & $* 0.19 \pm 0.11$ & 0.038 & $* 1.2 \pm 0.81$ & 0.287 & $* 0.6 \pm 0.03$ & 0.01 \\
\hline III & Soil & 12 & $\# 8.6 \pm 0.56$ & 0.16 & $\# 2.4 \pm 1.01$ & 0.291 & $\# 11.25 \pm 1.01$ & 0.29 & $\# 61.4 \pm 2.25$ & 0.650 & $\# 41.4 \pm 1.69$ & 0.48 \\
\hline
\end{tabular}

$\mathrm{N}=$ Number of samples, ND= Not detectable, $*$ =Lowest Mean values, \# = Highest Mean values, Metal concentration in $\mu \mathrm{g} / \mathrm{g}$ (ppm) dry weight and $\mu \mathrm{g} / \mathrm{ml}$ (ppm) wet weight. 


\section{Conclusions}

Our results shows that fecal matter can use as good bio-indicator for gross metal exposure and it provide a less expensive or better means of assessing long-term trends in pollution or other forms of environmental change. This method is completely non-invasive one to conserve the wildlife.

\section{Acknowledgment}

The authors acknowledge This work was supported by the Department of forestry, Govt. of Rajasthan., India.

\section{References}

[1] L. Boitani, and S. Bartoli, Simon and Schuster's guide to mammals (Simon and Schuster Inc, 1983).

[2] H.J. Temple, A. Cuttelod, The status and distribution of Mediterranean mammals (IUCN, International Union for Conservation of Nature and Natural Resources, New York, 2008).

[3] IUDZG/CBSG of IUCN/SSC, Executive summary, The World Zoo Consevation Strategy: The role of the zoos and aquaria of the world in global conservation (Chicago Zoological Society, U.S.A, 1993).

[4] A. Hopkins, Experimental lead poisoning in the baboon, Brit. J. Industr. Med., 27, 1970, 130-140.

[5] B.C. Zook, R.M. Sauer, F.M. Garner, Lead poisoning in captive wild animals, J. Wildl. Dis., 8,( 3), $1972,264-272$.

[6] J.W. Dollahite, R.L. Younger, and H.R. Crookshank, Chronic lead poisoning in horses, Am. J. Vet. Res. 39(6), 1978, 961-964.

[7] C.D. Goldsmith, and P.F. Scanlon, Lead levels in small mammals and selected invertebrates associated with highways of different traffic densities, Bull. Environ. Contam. Toxicol., 17, 1977, 311-316.

[8] W.N. Bayer, O.H. Pattee, L. Sileo, D.J. Hoffaman, and B.M. Mulhem, Metal contamination in wildlife living near two zinc smelters, Environ. Pollut. Ser A, 33, 1985, 63-86.

[9] E.H. Dustman, L.F. Stickel, and J.B. Elder, Mercury in wild animals from lake St. Clair. In Environmental mercury contamination, R. Hurtung and B.D. Dinman (Ed), (Ann Arbor, Mich., Ann Arbor Scince Publishers, 1972) 46-52.

[10] C.D.Wren, Probable case of mercury poisoning in a wild otter, Lutra Canadensis, in northern Ontario. Can. Field-Nat., 99, 1985, 112-114.

[11] D.R. Jr, Clark, Lead concentrations : bats vs terrestrial mammals collected near a major highway, Environ Sci Technol, 3, 1979, 338341.

[12] R.D. Roberts, and M.S. Johnson, Dispersal of heavy metals from abandoned mine working and their transference through terrestrial food chains, Environ. Pollut., 16, 1978a 293-310.

[13] R.D. Roberts, and M.S. Johnson, Lead contamination of small mammals from abandoned metalliferous mines, Environ. Pollut., 15, 1978b, 61-69.

[14] S.H. Andrew, M.S. Johnson, and J.A. Cooke, Cadmium in small mammals from grassland established on metalliferous mine waste, Environ. Pollut. Ser A, 33, 1984, 153-162.

[15] C.A. Way, and G.D. Schroder, Accumulation of lead and cadmium in wild population of the commensal rat, Rattus norvegegicus, Arch. Envron. Contam. Toxicol., 11, 1982, 407-417.

[16] R.F. Jr. Reidinger, Factors influencing Arizona bat population levels, Ph.D. Thesis, Univ. Arizona, Tucson, $1972,172$.

[17] M.G. Petit, and J.S. Altenbach, A chronological record of environmental chemicals from analysis of stratified vertebrate excretion deposited in a sheltered environment. Environ. Res. 6 (3), 1973, 339-343.

[18] D.R. Jr. Clark, K.L.V. Richard, and D.T. Merlin, Estimating pesticide burdens of bats from guano analysis, Bull. Environ. Contam. Toxicol.,29, 1982, 214-220.

[19] T. Kjellstrom, K. Borg, and B. Lind, Cadmium in feces as an estimator of daily cadmium intake in Sweden, Environ. Res., 15, 1978, $242-251$.

[20] L. Sileo, and W. N. Beyer, Heavy metals in white-tailed deer living near a zinc smelter in Pennsylvania, J. Wildl. Dis., 21, 1985, 289-296.

[21] M. David, K. Kaltis, M. Anver, J. Schwartz, A. Constan, R. Hurtung, B. Cohen, and D. Ringler, Arch. Environ. Health,. 30, 1975, 276-280.

[22] V. Gaumat, and P.P. Bakre, Mammalian dung as a bioindicator of heavy metal contamination, Proc. Acad. Environ. Biol. 7(1), 1998, 99-102.

[23] V. Gaumat, and P.P. Bakre, Metal contamination in mammalian fauna of Keoladeo National Park, Bharatpur (India), Environment and Agriculture: Biodiversity Agriculture and Pollution in South Asia, 2001, 577-580.

[24] V. Gupta, and P.P. Bakre, Metal contamination in mammalian fauna of Sariska tiger reserve, Alwar, India, Journal of Ecophysiology and Occupational Health, 12, 2012, 43-48.

[25] C. Leonzio, and A. Massi A. Metal bio-monitoring in bird eggs: A critical experiment. Bull. Environ. Contam. Toxicol. 43, 1989, 402-406.

[26] NEERI, Air Quality Status No. 6. 1991-92 (Wildlife Protection Act 1972) 1994

[27] P. Littele, and R.D. Wiffen, Emission and deposition of petrol engine exhaust Pb-I, Deposition of exhaust Pb to plant and soil surfaces, Atmos. Environ., 11, 1977, 437.

[28] P. Littele, R.D. Wiffen, Emission and deposition of lead from motor exhaust II. Airborne concentration, particle size and deposition of lead near motorway, Atmos. Environ., 12, 1978, 1331.

[29] P. Williamson, P.R. Evans, Lead: Leavels in roadside invertebrates and small mammals, Bull. Environ. Contam. Toxicol., 8, 1972, 280-288.

[30] C.R. Krishnamurti, and P. Vishwanathan., Toxic Metals in the Indian Environment, (Tata McGraw-Hill Publishing Company Limited, New Delhi, 1991) 188.

[31] C.D. Klaassen, Biliary excretion of metals, Drug Metab. Rev., 5, 1976, 165-96.

[32] A.E. Sobel, O. Gawron, and B. Kramer, Influences of vitamin D in experimental lead poisoning, Proc. Soc. Exp. Biol. Med, 38, $1938,433-435$.

[33] R.A. Goyer, Toxic effects of metals. In: casarett and Doull's Toxicology, The Science of Poison, (3 ${ }^{\text {rd }}$ Ed) C.D. Klaassen, (Macmillan Publishing Company, 1986) 582-653. 